\title{
First Polish Cowden syndrome patient with confirmed PTEN gene mutation
}

Marta Podralska ${ }^{1}$, Dorota Nowakowska ${ }^{2}$, Jan Steffen ${ }^{2}$, Wojciech Cichy ${ }^{3}$, Ryszard Slomski², Andrzej Plawski ${ }^{1}$

${ }^{1}$ Institute of Human Genetics, Polish Academy of Sciences, Poznań, Poland ${ }^{2}$ Genetic Counselling Unit, Cancer Centre and Institute of Oncology, Warsaw, Poland ${ }^{3}$ Karol Marcinkowski University of Medical Sciences, Poznań, Poland

Submitted: 24 April 2008

Accepted: 11 August 2008

Arch Med Sci 2010; 6, 1: 135-137

DOI 10.5114/aoms.2010.13522

Copyright $\Subset 2010$ Termedia \& Banach

\section{Corresponding author:}

Andrzej Plawski

Institute of Human Genetics Polish Academy of Sciences Strzeszynska 32 60-479 Poznań, Poland Phone: +48/61/657 9215 Fax: +48618233235

E-mail: andp@man.poznan.pl

\begin{abstract}
Cowden syndrome is a rare hereditary disease. Incidence of the disease is conditioned by occurrence of mutations in the PTEN gene. The disease has a frequency of $1 / 120,000$ newborn and it predisposes to the occurrence of hamartoma polyps in the gastrointestinal tract, skin tumours, as well as tumours of the breast, ovary and thyroid. Here we describe the case of a Polish patient diagnosed with Cowden syndrome with an identified mutation in the PTEN gene. The disease course of the patient is described and discussed along with other cases of carriers of substitution 68T >A in the PTEN gene.
\end{abstract}

Key words: Cowden syndrome, PTEN gene, Polish population.

\section{Introduction}

Cowden syndrome (CS) is also known as multiple hamartoma syndrome. Cowden syndrome was first described in 1963 by Lloyd and Dennis, who named the disease after their patient Rachel Cowden. It is a rare inheritable disease with autosomal dominant inheritance, characterised by skin findings and hamartomas. The first pathognomonic symptoms of CS are usually diagnosed in the second decade of life. Almost all patients develop hamartomas, which have ectodermal, mesodermal and endodermal origin. These multiple non-cancerous, tumour-like growths occur especially in skin, mucosal membranes, breasts, brain, endometrium and thyroid. More than $70 \%$ of patients with CS have hamartoma polyps in the gastrointestinal tract, mostly in the colorectum, but the polyps may also exist in the stomach and duodenum. Typical dermatopathology detected in CS comprises mucocutaneous lesions such as trichilemmomas, cobblestone-like papules, or acral or palmoplantar keratoses. Macrocephaly has been reported in $80 \%$ of cases. Other symptoms of CS, such as mental retardation and non-cancerous brain tumour called Lhermitte-Duclos disease, are observed infrequently. Among patients with CS, increased risk for many cancers is observed. The most common tumours are breast cancer in women, and thyroid cancer in both men and women. Carcinoma of thyroid and breast are present in approximately $60 \%$ and $20-36 \%$ of patients, respectively. Apart from adenocarcinoma of the colon or another part of the gastrointestinal tract, genitourinary cancer, lipomas, fibromas and neuromas have also been observed. Cowden syndrome is caused by 


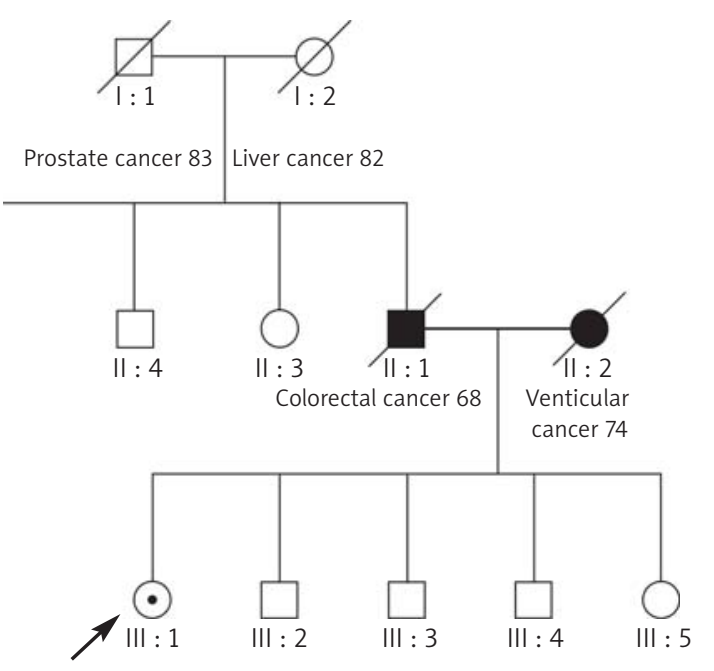

Figure 1. Pedigree data

\section{Control}

A T $G$ G A T T $T^{100}$ G A

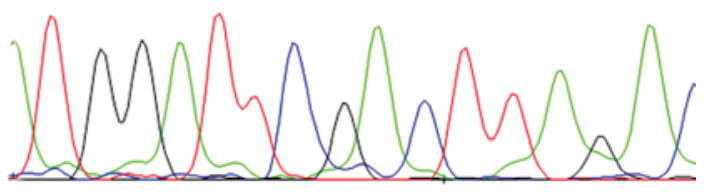

3400

\section{Affected 1003}

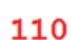

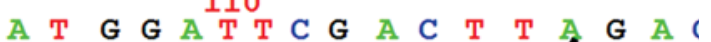

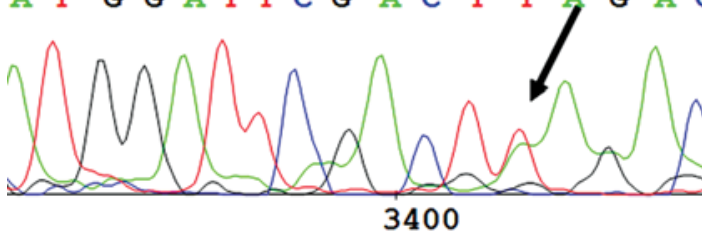

Figure 2. Sequencing of fragment of PTEN gene. Arrow indicates the substitution $68 \mathrm{~T}>\mathrm{A}$ mutation in the PTEN gene (also known as MMAC1 [mutated in multiple advanced cancers] or TEP1 [TGFregulated and epithelial cell-enriched phosphatase]) $[1,2]$. This tumour suppressor gene, encoding phosphatase with protein substrates, lies on chromosome 10q23. PTEN protein controls other molecules by removing phosphate groups. This cytoplasmic protein is involved in many cellular processes, and is active in various pathways, for example it negatively controls phosphoinositide 3-kinase signalling, plays a role in maintenance of cellular structure, interactions with the extracellular matrix, cell migration and invasion, and promotes cell death [3].

\section{Case report}

The patient was a 63-year-old woman with familial history of gastrointestinal cancers. Medical examinations showed the major criteria of the CS classification, i.e. macrocephaly, skin lesions, and endometrial and breast pathological changes. A $7 \mathrm{~cm}$ fibroma mole was removed from the left buttock at 53 years, and left and right mammary gland papillomas were removed at 57 years. An endometrial polyp was diagnosed at 47 years. The clinical diagnostic studies also confirmed sebaceous adenoma of head skin and colonoscopy revealed four hyperplasic polyps. Polyps were located in the descending colon and sigmoid colon. Moreover, a few diverticula were observed in the sigmoid colon. The patient underwent cholecystectomy performed at 48 years due to choledocholithiasis.

\section{Molecular studies}

Since 2006, in the Institute of Human Genetics, we have started examining hamartoma syndromes including CS. DNA was extracted from peripheral blood cells of the patient by the classical phenol purification method [4]. Exon 1 of the PTEN gene was amplified, using the following primers:

Table I. Clinical features of CS patients with 68T >A

\begin{tabular}{|c|c|c|c|c|c|c|c|}
\hline $\begin{array}{l}\text { Patient } \\
\text { (sex, age) }\end{array}$ & $\begin{array}{l}\text { Skin } \\
\text { lesion }\end{array}$ & Breast & Endometrium & Thyroid & CNS & Gastrointestinal & Others \\
\hline $\begin{array}{l}\text { Patient } 1^{*} \\
9031-2(F)\end{array}$ & + & $\mathrm{Ca}(46)$ & - & & - & - & - \\
\hline $\begin{array}{l}\text { Patient 2* } \\
\text { 903II-1 (F) }\end{array}$ & + & $\mathrm{Ca}(24)$ & - & Follicular ca (18) & - & - & $\begin{array}{c}\text { Liver } \\
\text { haemangioma }\end{array}$ \\
\hline $\begin{array}{l}\text { Patient } 3^{*} \\
\text { Pid1 (F) } \\
\text { (48) }\end{array}$ & + & $\mathrm{Ca}(24)$ & $\begin{array}{c}\text { Simple } \\
\text { hyperplasia } \\
\text { (43) }\end{array}$ & $\begin{array}{l}\text { Follicular } \\
\text { ca (13) }\end{array}$ & Macrocephaly & $\begin{array}{c}\text { Hyperplasic } \\
\text { colon polyps } \\
(423)\end{array}$ & $\begin{array}{c}\text { Liver } \\
\text { haemangioma } \\
\text { (35) }\end{array}$ \\
\hline $\begin{array}{l}\text { Patient } 4 \\
1003 \mathrm{~F}(64)\end{array}$ & + & $\begin{array}{l}\text { Papilloma } \\
\quad(57)\end{array}$ & $\begin{array}{l}\text { Polyp } \\
(46)\end{array}$ & & Macrocephaly & $\begin{array}{c}\text { Hyperplasic } \\
\text { colon polyps } \\
(614)\end{array}$ & - \\
\hline
\end{tabular}

The numbers in parentheses indicate the age of disease onset. Patients with * were described elsewhere by Lynch and Rustand (Lynch, Ostermeyer et al. 1997; Rustad, Bjrrnslett et al. 2006). CNS - central nervous system 
forward 5'-AGTCGCCTGTCACCATTT, and reverse ACTACGGACATTTTCGCATC. The entire coding sequence of the PTEN gene was screened for mutations using PCR-HD and PCR-SSCP analysis. The PCR product encompassing exon 1 of the PTEN gene, which showed an aberrant mobility pattern in polyacrylamide gel electrophoresis as compared with an unaffected control, was subjected to direct cycle sequencing. The sequence reaction product was analysed with an MEGA BACE 500 DNA sequencer.

\section{Discussion}

As a result of this study, we detected a mutation in the first exon of the PTEN gene. The detected mutation was a transversion of $\mathrm{T}$ to $\mathrm{A}$ at nucleotide 68 and caused premature protein termination, resulting in a change from TTA to TAA codon. The substitution $68 \mathrm{~T}>\mathrm{A}$ is the first mutation detected in a Polish patient with CS. The substitution $68 \mathrm{~T}>\mathrm{A}$ is located in the $\mathrm{N}$-terminal phosphatase domain. Three carriers of $68 \mathrm{~T}>\mathrm{A}$ have been described previously (Table I) $[5,6]$. We observed differences in relation to age and the range of disease symptoms in this group of patients (Table I).

All carriers of substitution $68 \mathrm{~T}>\mathrm{A}$ reveal skin lesions and breast tumours. However, in our patient (patient 4), the mammary gland papillomas were removed and no adenomatous changes, which had been described in all the other patients, were observed (Table I). Remaining disease symptoms were observed with considerable differentiation. Macrocephaly, and gastrointestinal and endometrial symptoms were only seen in patients 3 and 4 . The two remaining carriers of $68 \mathrm{~T}>\mathrm{A}$ demonstrated no such lesions. In the presented group of $68 \mathrm{~T}>\mathrm{A}$ carriers, both skin lesions and breast cancer were observed, while in one patient (patient 3) the course of CS was very severe $[5,6]$. The significant variation observed in the range and time of onset of disease symptoms in carriers of the same mutation allowed the authors to conclude that the course of the disease may be strongly affected by genetic background.

The present study is the first report of molecular confirmation of the clinical recognitions of CS with mutation in the PTEN gene in Poland. The genetic testing led us to identify individuals of high risk of cancer occurrence, until clinical diagnostic studies could be performed. Heterogeneity in the occurrence of symptoms is observed but some cancers may occur at a young age and the screening for cancer may be performed in teenagers.

\section{Acknowledgments}

The study was financed by the Ministry of Education and Science, Poland, grants number 2PO5E02630 and N N401 014435.

\section{References}

1. Nelen MR, van Staveren WC, Peeters EA, et al. Germline mutations in the PTEN/MMAC1 gene in patients with Cowden disease. Hum Mol Genet 1997; 6: 1383-7.

2. Nelen MR, Padberg GW, Peeters EA, et al. Localization of the gene for Cowden disease to chromosome 10q22-23. Nat Genet 1996; 13: 114-6.

3. Stiles B, Groszer M, Wang S, Jiao J, Wu H. PTENless means more. Dev Biol 2004; 273: 175-84.

4. Slomski R, et al. Isolacja DNA. Przykłady analiz DNA, 2001; 3-7.

5. Rustad C, Bjřrnslett M, Heimdal KR, Mșhle L, Apold J, Mřller P. Germline PTEN mutations are rare and highly penetrant. Heredit Cancer Clin Pract 2006; 4: 177-85.

6. Lynch ED, Ostermeyer EA, Lee MK, et al. Inherited mutations in PTEN that are associated with breast cancer, cowden disease, and juvenile polyposis. Am J Hum Genet 1997; 61: 1254-60. 